\title{
Development of Legal Framework within Educational and Professional Psychologist Practice in the Republic of Latvia
}

\author{
Dr. iur., Mg. art. Ivans Jānis Mihailovs \\ Ivans.Mihailovs@inbox.lv
}

\section{Abstract}

The aim of the research was to trace psychologist practice and educational development, as well as development of psychologist legal framework in the Republic of Latvia, by paying special attention to the essence of the Psychologist Law and related problems.

Psychologist Law promulgation has created necessary preconditions, in order to arrange the system of Latvian psychologist professional practice. However, no law is able to solve all challenges observed in any profession. It is clear that among such challenges there are not only different procedures, for example, psychologist registration, certification and recertification, but also professional improvement regulation and creation of good professional practice, and also constant progress of existing question about psychologist ethical professional practice, clearly positioning his service.

Keywords: psychologist educational and professional practice legal framework, Psychologist Law, requirements of psychologist professional practice.

\section{Introduction}

Psychology as a science and professional practice started gradually developing in the second part of the $19^{\text {th }}$ century in the land that belongs today to the Republic of Latvia $[9,12]$, but professional psychologist education was established by higher education institution, University of Latvia, more than hundred years later - only in 1989 [11]. In its turn, the first law that regulates psychologist practice, Psychologist Law, after more than a 15-year-long discussion, was enacted on 30 March 2017 (took effect on 1 January 2018).

Regulation of psychologist practice is important not just because a psychologist affects an individual and his health, but often a psychologist's decision (conclusion) can have an impact on a person's future life, activities, getting or saving different rights, and 
as $12 \%$ of the inhabitants of Latvia have admitted ${ }^{1}$, they feel need for psychologist or psychotherapist counselling, but have never turned to one. $3 \%$ of the Latvian population have visited a psychologist last within a year's time, $5 \%$ - one to four years ago, but $7 \%$ - even a longer time ago [10]. The above mentioned raises a question about psychologist service quality, security, confidentiality, clear counselling conditions, counselling documentation, psychologist service quality control and nominated educational and qualification improvement requirements to psychologist.

Thereby the aim of the research was to trace psychologist practice and educational development, as well as development of psychologist legal framework in the Republic of Latvia, by paying special attention to the essence of the Psychologist Law and related problems.

\section{Psychologist Education and its Regulations in the Republic of Latvia}

Psychologist preparation in the Republic of Latvia began in 1989. It was the time when the country not only became independent again, but education was gradually converting from the USSR higher education model (5 years of study) to Western widespread bachelor and master educational models.

Within a relatively short time, psychologist studies were transformed into professional studies, viz. four year bachelor's study (160 Latvian credit points ${ }^{2}, 240$ ECTS ${ }^{3}$ ), after acquiring a professional bachelor's degree and a professional psychologist-assistant qualification, and two years of master's study (80 Latvian credit points, 120 ECTS), after acquiring a professional master's degree and a professional psychologist qualification, or three years of academic bachelor's study (120 Latvian credit points, 180 ECTS), after acquiring an academic bachelor's degree and three years of professional master's study (120 Latvia credit points, 180 ECTS), after acquiring a professional master's degree and a professional psychologist qualification [15]. Professional qualification served as the foundation for further professional practice.

In its turn, three years of a $\mathrm{PhD}$ study programme, followed by promotion work presentation and by getting a PhD degree, gives a chance to prepare and perform scientific and academic work in the chosen field of psychology.

To get rights to offer higher education studies, the higher education institution has to receive a license for the appropriate study programme implementation; thus, the rights to provide a government recognised higher education document - diploma; the rights

1 The survey was performed among1003 Latvian population aged 18-74 years old in April, 2017.

2 Credit point - Latvian accounting unit, which is matched to a 40 -academic-hour capacity (one week study) [7].

${ }^{3}$ ECTS - European Credit Transfer and Accumulation System. 
Ivans Jānis Mihailovs. Development of Legal Framework within Educational and Professional Psychologist Practice in the Republic of Latvia

to grant a professional qualification are given when the study programme / appropriate field of study (viz. related study programmes, too) has undergone accreditation.

Considering professional higher education standard, professional bachelor's study programme must contain general education study courses, at least for 20 Latvian credit points - humanitarian and social sciences courses, including courses which develop social, communication and organisational basic skills; field (fields of professional activity) theoretical basic courses and informational technology courses at least for 36 Latvian credit points; field (fields of professional activity) professional specialisation courses at least for 60 Latvian credit points; state examination, where part of it is bachelor's thesis or diploma (diploma project) development and presentation, at least for 12 Latvian credit points.

Nevertheless, professional master's study programme must contain study courses that provide profound education of newest achievements in the field's (professional field) theory and practice, at least for five Latvian credit points; research, creative work, work project and management study courses for at least three Latvian credit points; state examination, where part of it master's thesis or diploma paper (diploma project) development and presentation, at least for 20 Latvian credit points [25].

Professional study programme specifics are related to a relatively large proportion of professional practice (in total at least 26 Latvian credit points, 39 ECTS, respectively within the professional bachelor's degree framework - 20 Latvian credit points and within professional master's degree framework - six Latvian credit points). Professional practice is implemented at a psychologist's work place and related to the necessity of validating theoretical knowledge received during the study period, as well as the possibility of receiving skills and abilities under the supervision of an experienced psychologist, thus being prepared for enactment of the duties of a psychologist.

In the course of time (until 2017), psychologist education in Latvia was offered by seven higher education institutions - government founded higher education institutions: University of Latvia, University of Daugavpils, Rīga Stradiňš University, Riga Teacher Training and Educational Management Academy (in 2017 it was consolidated to University of Latvia) and private institutions of higher education: International Higher School of Practical Psychology (closed down at the end of 2015) and High school of psychology (from 2010 - Baltic Psychology and Management Higher School, which in 2015 was consolidated to Baltic International Academy), as well as, recently, "RISEBA" University of Business, Arts and Technology.

It is now possible to acquire bachelor-master-PhD education in psychology in universities, while other higher educational institutions offer bachelor-master education in psychology.

For persons who received education in psychology abroad, there is an obligation to acknowledge that by receiving Latvian academic informational centre conclusion:

1) if educational received abroad document conforms to Latvian assigned higher education document; 
2) if there is a possibility to equalise to any assigned Latvian grade or diploma;

3) what additional conditions should be fulfilled, to equalise the educational document received abroad to any Latvian assigned academic grades or diploma, if abroad received academic grade or educational document does not satisfy any of the assigned Latvian grade or diploma requirements [15].

Such system in psychologist higher education was created and performed relatively successfully in Latvia until 2017, because in the enacted Psychologist Law psychologist education and professional practice rights have been separated, as well it has been defined that

"[a] person has the right to perform independent professional psychological practice confirmed by higher education diploma for accredited bachelor's study programme and accredited master's study programme and has acquired at least 200 Latvian credit points (300 ECTS); moreover, at least one of those programmes must be a professional study programme, requested is registration at the Psychologist register and certification that allows to work in the chosen psychological field" [20].

This means that reformation of higher education for psychologists will take place soon. On the one hand, it will be looking for better solution in bachelor and master's study programmes' optimisation and efficiency; on the other hand, better preparation of psychologists for certification during the studies will be ensured.

\section{Towards Psychologist Professional Practice Legislation}

Psychologist education and professional practice development in Latvia has raised the question about psychologist professional practice legislation. Nevertheless, the way to the Psychologist Law promulgation has been 15 years long, and it has been related to many debates.

It has been determined by many circumstances, among which the most highlighted have been psychologists' opinions, interests and diversity of psychological approaches. In Latvia, over 40 non-governmental organisations represent psychologist interests, different ideas about psychologist needs, psychologist duties, rights, responsibility, also fear of changes and fear that psychologist practice legislation will create additional costs and administrative burden to psychologists (for example, obligation to document cooperation with a client, obligation to pay taxes, relatively high costs for qualification improvement), which directly will increase prices for psychologist service and respectively will decrease the amount of clients, there are worries that psychologist certification and recertification models will be complicated, worries about psychologist specialization etc. $[1,2,4,6,7,13]$.

Another highly important issue is which governmental institution will be responsible for psychologists - Ministry of Health, Ministry of Welfare, Ministry of Science and Education, The State Chancellery of Latvia or Cross-Sectoral Coordination Centre. 
Ivans Jānis Mihailovs. Development of Legal Framework within Educational and Professional Psychologist Practice in the Republic of Latvia

Consequently, Psychologist Law development and further progress was committed to Cross-Sectoral Coordination Centre, which in 2014 prepared an informative report "About the necessity of regulating psychologists professional activities", which admitted that to provide unified psychologist service supervision and make it better in the long term, it is necessary to create psychologist certification system and provide supervision for psychologist professional practice, professional and general ethical consideration, as well as necessity for psychologist professional practice legislation [4].

In this context it should be emphasised that psychologist work covers many professional fields, which made it noticeably harder to develop psychologist professional practice legislation. Therefore, until 2017 in Latvia there was not created a general framework for psychologist practice, there were not defined psychologists' duties and rights, and, more importantly, there were not defined client rights, there was not created a unified certification system that would provide control for unified educational and professional experience requirement for psychologists that would guarantee good quality of psychologist service, there were not defined limitations for psychologist to perform professional practice if practice realisation was unqualified and made harm to a client [14].

At the same time, psychologist basic skills were included in psychologist profession standard ${ }^{4}$ and profession classifier ${ }^{5}$. Nevertheless, this regulation was quite general and was more related to psychologist education and work relation arrangement, rather than systematic psychologist professional practice regulation [22].

Considering the above mentioned, some fields of psychology were nominated specific (additional) educational, qualification and reputational requirements; for example, to work as a psychologist in educational institutions [17, 26], to work with children [19], to perform forensic psychological expertise [21] etc.

Only in 2013, as a known compromise, the psychologist conclusion structure and rights to create psychologist conclusion framework were defined in the Children's Rights Protection Law - psychologist conclusion about psychological assessment results for court, orphans' court, police and prosecutor's office cases, which are related with children's rights protection, who have obtained at least a master's degree in psychology and who has at least a 5-year professional experience working with children and families.

Psychologist conclusion contains:

1) institution where request came from;

2) psychological assessment goals;

3) psychological assessment time and place;

4) general information about child, which is or may be necessary in conclusion handing in process

\footnotetext{
4 Profession standard defines basic tasks and duties of professional practice, professional qualification requirements, necessary education, skills, competence and abilities to its performance [21].

${ }^{5}$ Profession classifier is a system-wide (trade, position, speciality) list, which is created to provide appropriate overview and comparison for international labour force [5].
} 
5) methods used for psychological assessment;

6) observation during assessment, client motivation and assessment limitations;

7) psychological assessment results and analysis;

8) justified conclusions and recommendations;

9) information about confidentiality;

10) psychologist's name, surname, degree, diploma number, high school, where diploma was given, assessment handing in date [16].

Furthermore, this law defines how to work with children, how to perform volunteer work, as well that according to the agreement, it is not allowed to give psychological assessment service to a psychologist:

1) who was convicted of criminal act related to violence of criminal threatening, regardless whether conviction was removed or cancelled;

2) who was convicted of criminal act against morality or sexual inviolability, regardless whether conviction was removed or cancelled;

3) whom court has applied prescribed medication (prescribed by the law).

Besides that, the Education Law article 50 defines that work as a teacher or psychologist in educational institution (because psychologist in educational institution is equal to a teacher [23]) cannot be granted to a person who was convicted for wilful criminal act (regardless whether conviction was removed or cancelled), except in cases when after removal or cancellation of conviction as determined by the Cabinet of Ministers, Education Quality Public Service has evaluated that it does not affect learners' interests and has allowed to work a previously convicted person (for wilful criminal act or a less serious crime), as well a disabled person, a person who does not speak the official language (Latvian) or a person who by court resolution has lost parental (care) rights [17].

Furthermore, all psychologists who work with children (viz. persons under 18 years old), are obliged to study the concept about children's right protection - a 40-academichour-long professional qualification improvement programme, and once every five years after learning the children's right programme - a 24-academic-hour educational programme of notion improvement about topicality in children's right protection [24].

In general, until the Psychologist Law was enacted, only in some public work fields there were defined requirements for psychologist education and work experience; nevertheless, this was partially defined and mutually diverse in different normative acts, which showed risks that psychologist service quality may not be guaranteed at an appropriate level, which could affect decision-making, as well as make harm to a person.

\section{The Essence of the Psychologist Law}

On 30 March 2017 the Parliament of Latvia, Saeima, in its third (final) reading enacted the Psychologist Law, which was announced by the president of Latvia on April 30, 2017. The law came into force on 1 January 2018. 
Ivans Jānis Mihailovs. Development of Legal Framework within Educational and Professional Psychologist Practice in the Republic of Latvia

The goal of this law is to regulate psychologist professional practice (viz. psychological assessment, preparation of psychologist conclusion, individual counselling, as well as service to groups or organisations, using professional notion and scientifically based methods), to provide qualified psychologist service. As can be seen, psychologist professional practice does not include psychological research or teaching (this was and still remains one of the discussion objects).

A psychologist can perform professional practice as an employee, by signing a contract with an employer, as a volunteer, by signing volunteer work contract, as employer or author, respectively signing contract with a company or royalty or self-employed person (viz. a person who gets income independently, without being involved as an employee in labour relations with an employer and by not taking any position that gives rights and reward).

In this context it is important to highlight that on the very same day, when the Psychologist Law was enacted, the law "Regarding regulated professions and recognition of professional qualifications" was also modified. Article $32^{7}$ of this law says that in the field of psychology regulated profession there is a psychologist who can perform his work independently, if he is certificated. In Latvia, the term "regulated profession" means regulated professional activity or regulated professional set of works, which can be enabled under the regulation of national law acts and practiced with an appropriate professional qualification.

"Regulated professions" in essence are related to the necessity to ensure professional work in accordance to certain quality requirements and criteria, if work is related to social interest protection, its security and health protection; to protect separate socially significant professions against unqualified people involvement, set for those professions high requirements; to provide the possibility of receiving professional qualification in the Republic of Latvia which will be admitted overseas, as well as the abroad received qualification to be admitted in Latvia; to encourage people to move around in the European Union countries and European Free Trade Association countries [18].

In the future a psychologist professional practice will be performed by people who have received higher education diploma for accredited bachelor's study programme and accredited master's study programme in psychology education with at least 200 Latvian credit points. Furthermore, at least one of those programmes is supposed to be a professional study programme, registered at the Psychologist register (which will be maintained by the Education Quality Public Service), and who received a psychologist certificate in at least one of psychologist work fields:

1) educational and school psychology;

2) work and organisational psychology;

3) clinical and health psychology;

4) legal psychology;

5) counselling psychology;

6) military psychology. 
Ivans Jānis Mihailovs. Development of Legal Framework within Educational and Professional Psychologist Practice in the Republic of Latvia

However, to work as a psychologist is restricted to people:

1) who do not have appropriate education;

2) who are not registered at the Psychologist register;

3) whose psychologist certificate has been suspended or cancelled and whose psychologist practice has been suspended or stopped, as well as to people whose psychologist practice has been suspended or stopped (usually if a psychologist has overstepped normative acts or professional ethical requirements);

4) who have been convicted as suspected or accused in criminal process for criminal act, related to violence or criminal threating, or for crime against morality or sexual inviolability;

5) who have been convicted as suspected or accused in criminal process for criminal act, related to violence or criminal threating, or for crime against morality or sexual inviolability, regardless if conviction was spent or cancelled;

6) who have been convicted as suspected or accused in criminal process for criminal act, related to violence or criminal threating, or for crime against morality or sexual inviolability, but exempted from penalty;

7) against whom criminal process for criminal act, which is related to violence or criminal threating, or for crime against morality or sexual inviolability, is terminated on unreasonable basis;

8) who have a trusteeship.

To make it possible for a psychologist to fully provide his service, in the Psychologist Law there is prescribed obligatory psychologist registration at the Psychologist register, further certification (certificate is given for seven years after all examination has been completed) and recertification. Thereby, under auspices of the Ministry of Education and Science there will be created a psychologist certification council, which will approve psychologist certification committee and psychologist ethical committee regulations and personal staff structure; it will approve psychologist ethical codex; organise psychologist certification, recertification and supervisor rights conferment, decision about psychologist registration at the register, psychologist professional practice suspension, termination and renewal, psychologist certificate issue, suspension, cancellation and renewal; make decision about supervisor (certificated psychologist, who has at least a 5-year-long personal practice experience in appropriate psychologist work field and who have passed psychologist-supervisor examination, acquiring the rights to perform psychologists' supervision - systematic cooperation with psychologist (individually or in group), which is based on mutual contract, which has a goal to supervise psychologist professional practice and fulfil their professional comprehension and competence, to ensure high quality of psychological service and psychologist readiness independently perform professional practice) assignment, suspension, cancellation and renewal; supervise and control psychologist professional practice; consider applications about psychologist professional practice, etc. 
It is envisaged that there will be created six certification commissions (according to psychologist professional fields), which will evaluate the received information from certificate applicant and will perform competence examination. Likewise certificate committee will evaluate complaints about psychologist professional practice and will give a conclusion to the psychologist certification council about decision making.

To ensure safe and qualitative psychologist professional practice, in the Psychologist Law there have been prescribed the following professional practice basic principles for a psychologist:

1) principle of responsibility;

2) principle of competence;

3) principle of confidentiality;

4) principle of client psychological prosperity;

5) principle of professional cooperation;

6) principle of client informing about psychological assessment goals and results;

7) principle of ethical attitude and behaviour;

8) principle of respect to human personality;

9) principle of honesty.

It also encompasses the requirement to psychologist conclusion structure, which in essence is identical to the Children's Rights Protection Law - Psychologist conclusion, which has been prepared in two copies, shows the following information:

1) customer and client;

2) psychological assessment goals;

3) psychological assessment time and place;

4) general information about client, which is or may be necessary in conclusionmaking process;

5) methods used for psychological assessment;

6) observation during assessment, client motivation and assessment limitations;

7) psychological assessment results and analysis;

8) reasoned conclusions and recommendations;

9) information about confidentiality;

10) date when conclusion is made;

11) psychologist's name, surname, certificate number and certificate date of issue.

At the same time, in the Psychologist Law there have been defined psychologist duties, rights and responsibilities about information non-proliferation and confidentiality requirement consideration. A psychologist's main duties are: appropriate method usage; storage of client information; ethical principle consideration; client informing about counselling goals; used method and results; salvation of client information, except cases described in normative acts or information sharing if it is agreed with a client, as well as an obligation to cooperate with other professional representatives and other psychologists in client issue resolving. To maintain the professional qualification and to be recertified, a psychologist is obliged to cooperate with psychologist-supervisor on regular basis, as well as enhance their own professional skills and competence. 
A psychologist is obliged to keep his conclusions and cooperation records for 10 years. In the same way, a psychologist is obliged to instantly, not longer than within 24 hours, inform law enforcement agencies or other competent institutions, about circumstances which a psychologist has found out during his professional practice, if there is a serious suspicion that immediate circumstance non-consideration can lead to criminal act against a human life, health, morality or sexual inviolability.

At the same time, a psychologist has rights to refuse of giving psychological service, if it can create a direct threat to a psychologist's life, health or security. In its turn, a psychologist's client has rights, in a comprehensive form, to receive information from a psychologist about the goal of counselling, psychological assessment methods, process, results and conclusions, as well as rights fully or partially to refuse a psychologist's service (except cases when, for example, assessment is obligatory), to address in writing the Psychologist certification council, to evaluate the application of a psychologist's professional practice.

Special protection is guaranteed to a psychologist's non-adult clients (viz. a person under 18 years old). Service to this client is allowed only if a client's legal representative (usually - a parent) is informed about the service and agreed with it in writing, except if:

1) it is the first counselling session, when this client came to a psychologist and after counselling there was made no conclusion;

2) counselling session is given to anonymous client, using electronic communications;

3) counselling session or psychologist's conclusion, or session overview is asked from an Orphan's court, law enforcement institution or other competent institution, informing about that legal representative;

4) non-adult client is 14 years old and has himself approached a psychologist.

The Psychologist Law transition prescribes psychologist certification special conditions when the law comes into force, viz. to a person who has until January 1, 2018 received psychologist education, which conforms at least to five years full-time studies, and has done professional psychologist practice which has documentary proof for at least three years during last five years, has rights to have independent psychologist professional practice without registration at the register and psychologist certificate until December 31, 2019. In its turn until December 31, 2018 the person may come to apply for a certificate to the psychologist certification council, to be:

1) registered at the Psychologist register and receive a psychologist certificate without examination, if this person can documentary prove professional practice at least for three years during last five years;

2) registered at the Psychologist register to receive a psychologist certificate without examination and receive psychologist-supervisor rights without examination, if this person can documentary prove professional practice at least for five years during last seven years $[8,20]$. 
Ivans Jānis Mihailovs. Development of Legal Framework within Educational and Professional Psychologist Practice in the Republic of Latvia

\section{Conclusion}

The Psychologist Law promulgation has created necessary preconditions, in order to arrange the system of Latvian psychologist professional practice. However, no law is able to solve all challenges observed in any profession. It is clear that among those challenges there are not only different procedures, for example, psychologist registration, certification and recertification, but also professional improvement regulation and creation of good professional practice, and also constant progress of existing question about psychologist ethical professional practice, clearly positioning his service.

In addition, one of the fears tropicalized lately, is the question about psychologist client protection, because a psychologist has an obligation to document his practice, as well as when it is necessary to be able to verify / provide proof, for example, in certification process.

In the same way, more detailed legal solutions will be necessary in order to regulate demands, rights, duties, responsibilities if a psychologist works in a specific work field, for example, in the multi-professional team at medical institution. No less disputable is a question about a psychologist's duty to take responsibility for their professional practice results, defining a problem of those results, and also the possibility of getting professional liability insurance for a psychologist. Thereby, it should be considered that no law is able to solve all professional work issues, but it can highlight the way to practice development, strengthening safe, qualitative and legal psychologist service, effectively protect service providers and clients. This means that psychologist professional practice law legislation in Latvia is still and will be developing.

\section{Psihologu izglītības un profesionālās darbības tiesiskā regulējuma attīstība Latvijas Republikā}

\section{Kopsavilkums}

Psihologiija kā zinātniskais virziens un profesionālās darbības prakse sāka pakāpeniski attīstīties tagadējās Latvijas Republikas teritorijā 19. gadsimta otrajā pusē, bet profesionālo psihologu sagatavošana, t. i., studijas augstākās izglītības iestādē - Latvijas Universitātē -, tika uzsāktas vairāk nekā gadsimtu vēlāk - tikai 1989. gadā. Savukārt pirmais likums, kas tieši regulē psihologu profesionālo darbību, - Psihologu likums, pēc vairāk nekā 15 gadu ilgām diskusijām ir pieṇemts 2017. gada 30. martā (stājās spēkā 2018. gada 1. janvārī).

Psihologu profesionālās darbības regulējums ir nozīmīgs ne tikai tādēl, ka psihologs tieši ietekmē cilvēku un viña veselību un bieži vien no psihologa lēmuma (atzinuma) ir atkarīga cilvēka turpmākā dzīve, nodarbinātība, dažādu tiesību ieguve vai saglabāšana, 
bet arī tādēl, ka 12 \% Latvijas iedzīvotāju atzīst, ka izjūt vajadzību pēc psihologa vai psihoterapeita konsultācijas, tomēr speciālistu nav apmeklējuši, $3 \%$ Latvijas iedzīvotāju pēdējo reizi pie psihologa vai psihoterapeita vērsušies pēdējā gada laikā, $5 \%$ - pirms viena vai četriem gadiem, savukārt $7 \%$ ir vērsušies pie speciālista vēl senāk. Minētais aktualizē jautājumu par psihologu pakalpojumu kvalitāti, drošỉbu, tostarp konfidencialitāti, skaidriem sadarbības noteikumiem, attiecību dokumentēšanu, pakalpojumu kvalitātes pārraudzību un psihologam izvirzìtajām izglìīibas, kvalifikācijas un pilnveides prasībām.

Līdz ar to šajā rakstā ir mēgināts izsekot psihologu izglìitibas un profesionālās darbïbas tiesiskā regulējuma attīstībai Latvijas Republikā, īpašu uzmanību pievēršot Psihologu likuma būtībai un ar to saistītajām problēmām.

Rakstā konstatēts, ka Psihologu likuma pien,emšana ir izveidojusi nepieciešamos priekšnosacỉjumus, lai sakārtotu Latvijas psihologu profesionālās darbỉbas sistēmu. Tomēr neviens likums nevar atrisināt visus izaicinājumus, kas ir vērojami katrā profesijā. Viena no problēmām, kas ir aktualizējusies pēdējā laikā, ir jautājums par psihologa klienta aizsardzību, jo psihologam ir pienākums savu darbỉbu dokumentēt, kā arī nepieciešamības gadījumā apliecināt vai pierādīt, piemēram, sertifikācijas procesā.

Tāpat tiesiskie risinājumi būs nepieciešami, detalizētāk reglamentējot prasības, tiesības, pienākumus, atbildību, ja psihologs darbojas kādā specifiskā darbības jomā, piemēram, ārstniecības iestādē, multiprofesionālas komandas sastāvā. Ne mazāk diskutējams ir arī jautājums par psihologa pienākumu uzṇemties atbildību par savas profesionālās darbības rezultātiem, šo rezultātu definēšanas problēmām, kā arĩ iespējamo psihologa profesionālās atbildības civiltiesisko apdrošināšanu. Tas arī nozīmē, ka psihologu profesionālās darbības tiesiskais regulējums Latvijas Republikā joprojām ir un būs attīstībā.

Atslēgvārdi: psihologa izglīīibas un profesionālās prakses tiesiskais regulējums, Psihologu likums, psihologa profesionālā prakse, prasības.

\section{References}

1. Ābelīte, L., (2014) Psihologu karš (Eng. War of psychologists). Available from https://www.pietiek. com/raksti/psihologu_kars

2. Avotinnš, V. (2014) Müze: Psihologus sertificēs un saskaldìs (Eng. The planned certification and splitting of psychologists). Available from http://nra.lv/latvija/124350-muze-psihologus-sertificesun-saskaldis.htm

3. Dzērve, L. (2015) Psihologu organizācijas aizvien nerod kopsaucēju par topošo likumu (Eng. Psychologist organisations cannot reach consensus about the proposed law). Available from http://www.lsm.lv/raksts/zinas/latvija/psihologu-organizacijas-aizvien-nerod-kopsauceju-partoposo-likumu.a127362/

4. Informatīvais ziṇojums "Par psihologu profesionālās darbïbas regulējuma nepieciešamību" (2014) (Eng. Informative report "About the necessity of psychologist professional activity regulation"). Online available from http://www.pkc.gov.lv/sites/default/files/inline-files/PKCZin_20140211_ psi.pdf 
Ivans Jānis Mihailovs. Development of Legal Framework within Educational and Professional Psychologist Practice in the Republic of Latvia

5. Jaunais Profesiju klasifikators (Eng. The New Profession Classificatory). Available from http:// www.lm.gov.lv/text/80

6. Latvijas Psihologu arodbiedrība. (2015) Psihologu atklātā vēstule (Eng. Latvian Psychologists' Union, Psychologists' open letter). Available from http://www.irlv.lv/blogi/profesijas/ psihologu-atklata-vestule

7. Latvijas psihologu sabiedriskās organizācijas aicina atbalstït jauno likumu (Eng. Psychologist social organisations of Latvia call for support for the new law). Available from http://www. medicine.lv/raksti/latvijas-psihologu-sabiedriskas-organizacijas-aicina-atbalstitjauno-likumu

8. Likumprojekta "Psihologu likums" sākotnējās ietekmes novērtējuma ziṇojums (anotācija) (2015) (Eng. Draft Law "The Psychologist Law” initial impact assessment report (abstract). Available from http://titania.saeima.lv/LIVS11/saeimalivs11.nsf/0/0F4592F4A7F1594AC2257D250025C 497? OpenDocument

9. Mārtinsone, K., Lasmane, A., Karpova, Ā. (2016) Psihologijas vesture (Eng. History of psychology). Rìga: Zvaigzne ABC.

10. Pètījums: $12 \%$ iedzìvotāju izjūt vajadzību pēc psihologa vai psihoterapeita, taču speciālistu nav apmeklējuši (2017) (Eng. Research: 12\% of the inhabitants feel the needs towards psychologist and psychotherapist services, yet have never visited one). Available from http://apollo.tvnet.lv/ zinas/12-latvijas-iedzivotaju-izjut-vajadzibu-pec-psihologa-vai-psihoterapeita-tacu-specialistunav-apmeklejusi/797878

11. Psihologija Latvijā: psihologi, izglītība, profesionālā darbība (2012) (Eng. Psychology in Latvia: psychologists, education, professional activity). K. Mārtinsone, sast. Rīga: RaKa, 2012.

12. Renǵge, V., Dragūns, J. (2012) Psychology in Latvia: Its origins, development, and current state. European Psychologist, 17(3), 246-252.

13. Vairāk nekā 230 psihologi vēršas Saeimā pret Psihologu likumu. (2015) (Eng. More 230 psychologists approach the Parliament to oppose the Psychologist Law). Available from https://medicine. lv/raksti/vairak-neka-230-psihologi-versas-saeima-pret-psihologu-likumu

14. Vesperis, V. (2015) Mìti un patiesība par Psihologu likumu (Eng. Myths and Truths about the Psychologist Law). Online available from http://www.medicine.lv/raksti/ vesperis-miti-un-patiesiba-par-psihologu-likumu

\section{Legal acts}

15. Augstskolu likums (Eng. Higher Education Law). Available from https://likumi.lv/doc. php?id=37967

16. Bērnu tiesību aizsardzības likums (Eng. Children's Rights Protection Law). Online available from https://likumi.lv/doc.php?id=49096

17. Izglittības likums (Eng. Education Law). Available from https://likumi.lv/doc.php?id=50759

18. Likums "Par reglamentētajām profesijām un profesionālās kvalifikācijas atzī̌anu" (Eng. Law "Regarding regulated professions and recognition of professional qualifications"). Available from https://likumi.lv/doc.php?id=26021

19. Profesionālās izglìtības likums (Eng. Professional Education Law). Available from https://likumi. lv/doc.php?id=20244

20. Psihologu likums (Eng. Psychologist Law). Available from https://www.vestnesis.lv/op/2017/75.1

21. Tiesu ekspertu likums (Eng. Forensic Expert Law). Available from https://likumi.lv/doc. php?id=280576 
Ivans Jānis Mihailovs. Development of Legal Framework within Educational and Professional Psychologist Practice in the Republic of Latvia

22. Ministru kabineta 2014. gada 26. augusta noteikumi Nr. 512 "Noteikumi par otrā lìmena profesionālās augstākās izglìtības valsts standartu" (Eng. Regulation No. 512 of August 26, 2014 of the Cabinet of Ministers "Regulations about the national standard of the second level professional higher education"). Available from https://likumi.lv/doc.php?id=268761

23. Ministru kabineta 2014. gada 1. aprīla noteikumi Nr. 173 "Noteikumi par kārtību, kādā apgūst speciālās zināšanas bērnu tiesību aizsardzības jomā, šo zināšanu saturu un apjomu” (Eng. Regulation No. 173 of April 1, 2014 of the Cabinet of Ministers "Regulations about specific knowledge acquisition of children's rights protection, the contents and aptitude of such knowledge"). Available from https://likumi.lv/doc.php?id=265516

24. Ministru kabineta 2011. gada 19. maija noteikumi Nr. 354 "Noteikumi par pedagogu profesiju un amatu sarakstu" (Eng. Regulation No. 354 of May 19, 2011 of the Cabinet of Ministers "Regulations about the list of education profession sand positions"). Available from https://likumi.lv/doc. php?id=229913

25. Ministru kabineta 2014. gada 28. oktobra noteikumi Nr. 662 "Noteikumi par pedagogiem nepieciešamo izglìtību un profesionālo kvalifikāciju un pedagogu profesionālās kompetences pilnveides kārtìbu" (Eng. Regulation No. 662 of October 28, 2014 of the Cabinet of Ministers "Regulations about the required education and professional qualification for educators and development of their professional competence"). Available from https:/likumi.lv/ta/id/269965-noteikumi-parpedagogiem-nepieciesamo-izglitibu-un-profesionalo-kvalifikaciju-un-pedagogu-profesionalaskompetences-pilnveides

26. Ministru kabineta 2010. gada 28. maija noteikumi Nr. 461 "Noteikumi par Profesiju klasifikatoru, profesijai atbilstošiem pamatuzdevumiem un kvalifikācijas pamatprasībām un Profesiju klasifikatora lietošanas un aktualizēšanas kärtību” (Eng. Regulation No. 461 of May 28, 2010 of the Cabinet of Ministers "Regulations about profession classificatory, professionally relevant basic tasks and classification requirements, and procedure of professional classificatory usage and actualisation"). Available from https://likumi.lv/doc.php?id=210806 